\title{
A Mixed Micelle Formulation for Oral Delivery of Vitamin K
}

\author{
Feilong Sun ' - Tessa C. C. Jaspers' ${ }^{\text {'Peter M. van Hasselt }}{ }^{2}$ - Wim E. Hennink' \\ Cornelus F. van Nostrum '
}

Received: 1 April 2016 / Accepted: 23 May 2016 / Published online: 31 May 2016

(C) The Author(s) 2016. This article is published with open access at Springerlink.com

\begin{abstract}
Purpose To develop a stable micellar formulation of vitamin $\mathrm{K}$ for oral delivery, because the commercial and clinically used formulation of vitamin $\mathrm{K}$ (Konakion ${ }^{\circledR} \mathrm{MM}$ ) destabilizes at gastric $\mathrm{pH}$ resulting in low bioavailability of this vitamin in neonates with cholestasis.

Methods Mixed micelles composed of EPG, DSPE-PEG 2000 and glycocholic acid, with and without vitamin K, were prepared by a film hydration method. The influence of $\mathrm{pH}$ on the stability of the micelles was analyzed by dynamic light scattering (DLS). The critical micelle concentration (CMC) was determined by fluorescence spectroscopy using pyrene and the morphology was evaluated by transmission electron microscopy. Caco-2 cells were used to study the cytocompatibilty.
\end{abstract}

Results Mixed micelles with mean diameters from 7.1 to $11.0 \mathrm{~nm}$ and a narrow size distribution $(\mathrm{PDI}<0.2)$ were obtained after 3 membrane extrusion cycles. Konakion ${ }^{\circledR}$ MM formed aggregated particles at gastric $\mathrm{pH}$, which was avoided through steric stabilization by introducing PEG. TEM showed that mixed micelles had a spherical size (diameter of around $10 \mathrm{~nm}$ ) with a narrow size distribution in agreement with the DLS results. The loading capacities for vitamin K of mixed micelles with varying molar fractions of DSPE-PEG and EPC (from $0 / 100$ to $50 / 50(\mathrm{~mol} / \mathrm{mol})$ ) were $10.8-5.0$ $\mathrm{w} \%$, respectively. The mixed micelles showed good

Electronic supplementary material The online version of this article (doi: | 0. I 007/s | | 095-0 | 6-1954-9) contains supplementary material, which is available to authorized users.

Cornelus F. van Nostrum

C.FvanNostrum@uu.nl

Department of Pharmaceutics, Utrecht Institute for Pharmaceutical Sciences, Utrecht University, 3584 CG Utrecht, The Netherlands

2 Department of Pediatrics, Wilhelmina Children's Hospital, University Medical Center Utrecht, Lundlaan 6, 3584 EA Utrecht, The Netherlands cytocompatibility at concentrations of glycocholic acid between 0.12 and $1.20 \mathrm{mM}$.

Conclusions Mixed micelles with superior stability to Konakion ${ }^{\circledR} \mathrm{MM}$ at low $\mathrm{pH}$ were obtained by introducing DSPE-PEG 2000. These are therefore attractive oral formulations for vitamin $\mathrm{K}$.

KEY WORDS Konakion ${ }^{\circledR} M M$. Mixed micelles .

PEGylation · pH stability · Vitamin K

\section{ABBREVIATIONS}

EPC

DSPE-PEG 1,2-distearoyl-sn-glycero-3-

2000 phosphoethanolamine-

TEM N-[methoxy(polyethyleneglycol)-20

DLS Dynamic light scattering

CMC The critical micelle concentration

VKDB Vitamin $\mathrm{K}$ deficiency bleeding

MM $\quad$ Mixed micelles

PP Packing parameter

$\checkmark \quad$ Molecular volume

Ao $\quad$ Polar surface cross-area

$L \quad$ Length of the hydrophobic chain

FaSSGF Fasted state simulated gastric fluid

PMS N-Methyl dibenzopyrazine methylsulfate

XTT Sodium 3'-[1-(phenylaminocarbonyl)-3,4-tetrazolium] -bis(4-methoxy-6-nitro)benzene sulfonic acid hydrate)

\section{INTRODUCTION}

Vitamin $\mathrm{K}$ is an essential cofactor for $\boldsymbol{\gamma}$-glutamyl carboxylase, an enzyme that catalyzes the carboxylation of glutamic acid residues in a number of proteins that are involved in the blood 
coagulation (1). In healthy adults, bile that is secreted into the intestine facilitates the solubilization, transport and uptake of vitamin $\mathrm{K}$ present in food (2). Therefore, dietary deficiency of vitamin $\mathrm{K}$ is rare in adults, except for patients suffering from intestinal disorders and malabsorption (3). On the other hand, vitamin $\mathrm{K}$ deficiency does frequently occur in neonates due to limited transport of vitamin $\mathrm{K}$ through the placental barrier and low concentration in breast milk (main exogenous source of vitamin $\mathrm{K}$ in neonates) (4). This in turn is associated with the risk of life-threatening vitamin $\mathrm{K}$ deficiency bleeding (VKDB), which is due to the low activity of vitamin Kdependent coagulation factors (II, VII, IX, X) (5). Konakion ${ }^{\circledR}$ mixed micelles (MM) Paediatric is a formulation composed of vitamin $\mathrm{K}$, egg phosphatidylcholine (EPG or lecithin) and glycocholic acid (6). It is indicated for both the prophylaxis and treatment of VKDB in neonates as well as infants. However, orally administered Konakion ${ }^{\circledR}$ MM fails to prevent $\mathrm{VKDB}$ in cholestatic infants due to impaired intestinal absorption of vitamin $\mathrm{K}(7)$, which is due to the pathophysiological conditions in the upper gastrointestinal tract of those infants. Glycocholic acid has a carboxylic acid group with a pKa of 3.8 (8), which ensures a good colloidal stability of the mixed micelles above $\mathrm{pH}>\sim 4$. However, Konakion $\AA$ $\mathrm{MM}$ is unstable and forms large aggregates at low $\mathrm{pH}$ of the stomach because of the protonation of the carboxylate group of glycocholic acid, eventually causing coalescence of the formulation (9). After stomach passage, large aggregates of lipids and coalesced vitamin $\mathrm{K}$ enter the duodenum, which under normal physiological conditions can subsequently be solubilized by endogenous bile salts (10,11), pancreatic lipases and elevated $\mathrm{pH}$ above the $\mathrm{pKa}$ of glycocholic acid $(12,13)$. On the other hand, once large aggregates are formed in the stomach of neonates suffering from cholestasis, coalesced vitamin $\mathrm{K}$ cannot be solubilized due to the very low level of bile salts in these patients $(13,14)$.

Mixed micelles composed of phospholipids and bile salts were first described by Hoffman and Borgstrom (15) as associated amphiphilic biliary and dietary components. The hydrophobic tails of EPC molecules are positioned in the core of the mixed micelles to minimize their contact with water molecules while their polar head groups are present at the interface with water (16). It has been further shown that phospholipids self-assemble into bilayered structures in aqueous solution, whereas mixed micelles are formed in the presence of bile salts (16). These structures can solubilize poorly watersoluble drugs in the inner micellar core (17). Furthermore, mixed micelles are thermodynamically stable with sizes usually ranging from 5 to $60 \mathrm{~nm}$ (18). Particles with such small diameters are necessary to transport vitamin $\mathrm{K}$ to the surface of enterocytes and to retain mixed micelles at the base of microvilli (19).

The aim of this study was to develop a mixed micellar formulation of vitamin $\mathrm{K}$ that is stable at low $\mathrm{pH}$ and therefore suitable for oral administration. Therefore, part of EPC of the Konakion ${ }^{\circledR}$ MM formulation was substituted by a PEGylated lipid (DSPE-PEG 2000). The rationale behind this idea is that PEGylated phospholipids are known to act as a steric barrier stabilizing nanostructures such as liposomes (20,21), micelles (22), disks (23) and dendritic nanocarriers (24), and will thereby enhance the stability of drug loaded formulations at neutral as well as acidic pH. For example, Torchilin et al. have shown that DSPE-PEG 2000/D- $\alpha$ tocopheryl PEG 1000 succinate (TPGS) micelles are stable at low pH (25). PEGylated lipids have so far not been a component of endogenous lecithin/bile salt mixed micelles to enhance their stability at low $\mathrm{pH}$. Yet, those bile salt-lipids based mixed micelles expose unique possibilities to enhance the permeability of hydrophobic drugs in the intestine (26). Furthermore, EPC, glycocholic acid and DSPE-PEG 2000 are all components approved by U.S. FDA. Therefore, to mimic the endogenous mixed micelles, a mixed micellar formulation based on above components for vitamin $\mathrm{K}$ is preferred instead of for instance polymeric micelles, which can also remain stable at acidic condition.

The size and $\mathrm{pH}$ stability of mixed micelles composed of varying ratios of DSPE-PEG/EPG were analyzed by dynamic light scattering (DLS). Extrusion effects on the size of mixed micelles during filtration were investigated using DLS and TEM. The loading capacity of vitamin $\mathrm{K}$ for mixed micelles composed of DSPE-PEG /EPG 50/50 (mol/mol) was optimized. Furthermore, cell viability studies were conducted with Caco-2 cells to evaluate the cytocompatibility of the mixed micelles.

\section{MATERIALS AND METHODS}

\section{Materials}

Lecithin (egg phosphatidylcholine, EPG) and 1,2-distearoylsn-glycero-3-phosphoethanolamine-poly(ethylene glycol) 2000 (DSPE-PEG 2000) were kindly provided by Lipoid GmbH (Ludwigshafen, Germany). Potassium phosphate monobasic $\left(\mathrm{KH}_{2} \mathrm{PO}_{4}\right)$ and sodium phosphate dibasic dihydrate $\left(\mathrm{Na}_{2} \mathrm{HPO}_{4} \cdot 2 \mathrm{H}_{2} \mathrm{O}\right)$ were purchased from SigmaAldrich (Zwijndrecht, The Netherlands) and used to prepare $0.067 \mathrm{M}$ phosphate buffer $\left(0.35 \mathrm{~g} \mathrm{KH}_{2} \mathrm{PO}_{4}\right.$ and $1.45 \mathrm{~g}$ $\mathrm{Na}_{2} \mathrm{HPO}_{4} \cdot 2 \mathrm{H}_{2} \mathrm{O}$ in $100 \mathrm{ml} \mathrm{RO-water,} \mathrm{pH} \mathrm{7.3).} \mathrm{Sodium}$ chloride were purchased from Merck KGaA (Darmstadt, Germany). Sodium phosphate monobasic monohydrate $\left(\mathrm{NaH}_{2} \mathrm{PO}_{4} \cdot \mathrm{H}_{2} \mathrm{O}\right)$ and Pepsin from porcine stomach mucosa was provided by Sigma-Aldrich (Zwijndrecht, The Netherlands). Vitamin K, glycocholic acid hydrate, fetal bovine serum $(\mathrm{FBS}$ ) and all other chemicals and reagents were obtained from Sigma-Aldrich (Zwijndrecht, The Netherlands). Chloroform was provided from Biosolve 
(Valkenswaard, the Netherlands). Sodium hydroxide $(\mathrm{NaOH}), 70 \%$ perchloric acid, hexa-ammoniummolybdate $\left(\left(\mathrm{NH}_{4}\right)_{6} \mathrm{M}_{\mathrm{O} 7} \mathrm{O}_{24} \cdot \mathrm{H}_{2} \mathrm{O}\right)$ and ethanol were supplied by Merck KGaA (Darmstadt, Germany). $\mathcal{N}$-Methyl dibenzopyrazine methylsulfate (PMS) and sodium 3'-[1-(phenylaminocarbonyl)-3,4-tetrazolium]-bis(4-methoxy6-nitro)benzene sulfonic acid hydrate) (XTT) were provided from Sigma. Dulbecco's Modified Eagle's Medium (DMEM) and RPMI 1640 medium were purchased from GibCo BRL Life Technologies (Carlsbad, CA, USA). Syringe filters were obtained from Phenomenex $(0.2 \mu \mathrm{m}$, Torrance, CA). Ultrapure water was produced by a Synergy UV water delivery system from Millipore (Billerica, MA, USA). Konakion ${ }^{\circledR}$ MM was a product manufactured by Roche (Basel, Switzerland).

\section{METHODS}

\section{Preparation of Empty Micelles}

Various amounts of EPG and DSPE-PEG 2000 were dissolved in $4 \mathrm{ml}$ chloroform in a round-bottom flask (Table I). The solvent was evaporated under vacuum at $60^{\circ} \mathrm{C}$ for $20 \mathrm{~min}$ to form a film. Next, glycocholic acid hydrate $(110 \mathrm{mg}$ ) was dissolved in $8 \mathrm{ml} 0.067 \mathrm{M}$ phosphate buffer at $60^{\circ} \mathrm{C}$ and the obtained solution was subsequently added to hydrate the above mentioned film of EPG and DSPE-PEG 2000. A transparent dispersion was obtained after magnetically stirring for at least $4 \mathrm{~h}$ at room temperature. The dispersion was subsequently extruded 3 times through a syringe filter.

\section{Preparation of Vitamin K Loaded Micelles}

Vitamin $\mathrm{K}(1 \mathrm{~g})$ was dissolved in $10 \mathrm{ml}$ chloroform. Next, $0.2 \mathrm{ml}$ of this vitamin $\mathrm{K}$ solution was added to $3.8 \mathrm{ml}$ chloroform in which the different amounts of lipids (EPC and DSPEPEG 2000) were dissolved (Table I). The solvent was evaporated under vacuum at $60^{\circ} \mathrm{C}$ for $20 \mathrm{~min}$ to form a film. Next, glycocholic acid hydrate $(110 \mathrm{mg}, 0.24 \mathrm{mmol})$ was dissolved in $8 \mathrm{ml} 0.067 \mathrm{M}$ phosphate buffer at $60^{\circ} \mathrm{C}$ and the obtained

Table I Mixed Micelles Composed of DSPE-PEG, EPC and Glycocholic Acid

\begin{tabular}{lllll}
\hline Component & \multicolumn{4}{l}{ Formulations } \\
\cline { 2 - 5 } & A & B & C & D \\
\hline DSPE-PEG 2000 (mmol) & - & 0.02 & 0.06 & 0.10 \\
EPC $(\mathrm{mmol})$ & 0.20 & 0.18 & 0.14 & 0.10 \\
DSPE-PEG/EPC (mol/mol) & $0 / 100$ & $10 / 90$ & $30 / 70$ & $50 / 50$ \\
\hline
\end{tabular}

The amounts of glycocholic acid and total lipids in the formulations were 0.24 and $0.20 \mathrm{mmol}$, respectively solution was subsequently added to hydrate the above mentioned film of EPC, DSPE-PEG 2000 and vitamin K. A transparent dispersion was obtained after magnetically stirring for at least $4 \mathrm{~h}$ at room temperature. The dispersion was subsequently extruded 3 times through a syringe filter. The dispersions were covered with aluminized foil to protect Vitamin K against light-triggered degradation during the whole procedure (27).

To investigate the vitamin $\mathrm{K}$ loading capacity of the DSPE-PEG/EPG 50/50 mixed micelles, DSPE-PEG $(288 \mathrm{mg}, 0.10 \mathrm{mmol})$ and EPG $(80 \mathrm{mg}, 0.10 \mathrm{mmol})$ were dissolved in $4 \mathrm{ml}$ chloroform in a round-bottom flask. Next, 0.4 or $0.8 \mathrm{ml}$ of vitamin $\mathrm{K}$ stock solution $(100 \mathrm{mg} / \mathrm{ml}$ in chloroform) was added. The following steps were the same as described above until a transparent dispersion was obtained. Then the obtained micellar dispersions were further diluted ten times with $0.067 \mathrm{M}$ phosphate buffer before filtration to avoid occulation of the filter. Subsequently, the dispersions were extruded 6 times through a filter.

\section{Characterization of Mixed Micelles}

Average size and size distribution of the different mixed micelles dispersed in $0.067 \mathrm{M}$ phosphate buffer were measured by Dynamic Light Scattering (DLS; Zetasizer 4000, Malvern Instruments, Malvern, UK) at $25^{\circ} \mathrm{C}$ and at an angle of $90^{\circ}$. The morphology of the mixed micelles was studied by Transmission Electron Microscopy (TEM, Tecnai 10, Philips, and $100 \mathrm{kV}$ ). The samples for TEM visualization were prepared according to the following procedure. A sample of the mixed micelles dispersion $(10 \mu \mathrm{l})$ was pipetted onto parafilm and a carbon-coated copper grid subsequently was placed on the sample for 4 min. Next, the excess liquid was removed by filter paper and subsequently the grid was negatively stained by being placed on a $10 \mu \mathrm{l}$ droplet of $2 \%$ uranyl acetate in demineralized water for $1 \mathrm{~min}$. Next, the excess liquid was removed using a filter paper and the grid was dried for $5 \mathrm{~min}$ at room temperature before the measurement. The zeta-potential ( $\zeta$ potential) of the mixed micelles was determined by Zetasizer (Malvern Instruments Ltd.). Prior to the measurements, phosphate buffer was exchanged by $10 \mathrm{mM}$ Hepes buffer pH 7.4 using PD-10 column chromatography. The instrument was calibrated using a standard (DTS1235, $-42.0 \pm 4.2 \mathrm{mV}$, Malvern Instruments, UK).

\section{Determination of the Critical Micelle Concentration (CMC)}

The GMC of the mixed micelles was determined using pyrene as a fluorescent probe (28). In detail, empty micelles composed of EPC only and DSPE-PEG/EPC $(50 / 50, \mathrm{~mol} / \mathrm{mol}$, formulations A and D, Table I) were prepared as described in the section "Preparation of Empty Micelles". Next the micellar 
dispersions were diluted with $0.067 \mathrm{M}$ phosphate buffer to different concentrations from $5.9 \times 10^{-6}$ to $29.5 \mathrm{mM}$ glycocholic acid (and $5.2 \times 10^{-6}$ to $25.8 \mathrm{mM}$ total lipids). Next, $18 \mu \mathrm{l}$ of pyrene in acetone $\left(1.8 \times 10^{-4} \mathrm{M}\right)$ was added to $4.5 \mathrm{ml}$ of each micellar dispersion. The micellar dispersions with pyrene were incubated for $20 \mathrm{~h}$ at room temperature in the dark to allow evaporation of acetone. Fluorescence excitation spectra of pyrene were recorded using a Horiba Fluorolog fluorometer (at a $90^{\circ}$ angle). The excitation spectra (300 to $360 \mathrm{~nm}$ with emission wavelength of $390 \mathrm{~nm}$ ) were recorded at $37^{\circ} \mathrm{C}$. The excitation and emission band slits were 4 and $2 \mathrm{~nm}$, respectively. The excitation intensity ratio of $\mathrm{I}_{338} / \mathrm{I}_{333}$ was plotted against the concentration of glycocholic acid to determine the CMC, which was obtained as the point of intersection of two tangents drawn to the curve at high and low concentrations, respectively (29).

\section{Stability of the Micelles}

Two milliliter of vitamin $\mathrm{K}$ loaded micellar dispersions composed of various amounts of DSPE-PEG/EPC (see Table I, prepared as described in section "Preparation of Vitamin K Loaded Micelles") were diluted 2.5 times by addition of $3 \mathrm{ml}$ $0.067 \mathrm{M}$ phosphate buffer. For $\mathrm{pH}$ stability study, the $\mathrm{pH}$ of the micellar dispersions was stepwise lowered from 7.2 to 1.6 by addition of $1 \mathrm{M} \mathrm{HCl}$. After each step, the dispersions were incubated for $5 \mathrm{~min}$ at $25^{\circ} \mathrm{C}$ and the size of the micelles was measured by DLS at the same temperature. Subsequently, the $\mathrm{pH}$ of dispersions was raised stepwise from 1.6 to 7.0 by adding $1 \mathrm{M} \mathrm{NaOH}$ and after each step the dispersions were incubated for $5 \mathrm{~min}$ at $25^{\circ} \mathrm{C}$ before measuring the size of the micelles. For determination of vitamin $\mathrm{K}$ recovery, the $\mathrm{pH}$ of the mixed micelles was lowered to 1.6 with $1 \mathrm{M} \mathrm{HCl}$ and the dispersions were subsequently incubated for $1 \mathrm{~h}$ at $37^{\circ} \mathrm{C}$. Subsequently, the dispersions were centrifuged at $1000 \times g$ for $1 \mathrm{~min}$ and $0.1 \mathrm{ml}$ of the different supernatants was diluted with $1 \mathrm{ml}$ ethanol to dissolve the mixed micelles and the vitamin $\mathrm{K}$ content was measured by HPLC as described below.

To mimic gastric stability at in viwo conditions, fasted state simulated gastric fluid (FaSSGF) was used, without bile salts (30). $1.50 \mathrm{ml}$ mixed micelles composed of EPG only (Konakion ${ }^{\circledR M M}$ ) and DSPE-PEG/EPG (50/50, $\mathrm{mol} / \mathrm{mol}$ ) with different concentrations of vitamin $\mathrm{K}$ (from 0.625 to $5.0 \mathrm{mg} / \mathrm{ml}$ ) was added to $0.75 \mathrm{ml} \mathrm{FaSSGF}(20.0 \mu \mathrm{M}$ lecithin, $34.2 \mathrm{mM} \mathrm{NaCl}$ and $0.1 \mathrm{mg} / \mathrm{ml}$ Pepsin, $\mathrm{pH} 1.5$ ) and $0.24 \mathrm{ml}$ $1 \mathrm{M} \mathrm{HCL}$ (to adjust $\mathrm{pH}$ to 1.5 ). The mixture was incubated at $37^{\circ} \mathrm{C}$ for $1 \mathrm{~h}$ with slow rotating.

\section{Determination of Vitamin K by HPLC Analysis}

The concentration of vitamin $\mathrm{K}$ in the dispersions of the different mixed micelles was determined by RP-HPLC after dilution with ethanol. A SunFire $\mathrm{C}_{18}$ column was used and absorption at $254 \mathrm{~nm}$ was used for detection. The mobile phase was ethanol/water $(95 / 5, v / v)$. The column temperature was $30^{\circ} \mathrm{C}$. The injection volume was $20 \mu \mathrm{l}$. A calibration curve was obtained using vitamin $\mathrm{K}$ dissolved in ethanol with concentrations ranging from 19.8 to $181.8 \mu \mathrm{g} / \mathrm{ml}$.

\section{Determination of Lipid Recovery}

The lipid recovery was determined using a method based on the colorimetric determination of $\mathrm{PO}_{4}{ }^{3-}$ according to Rouser (31). The phospholipid content of the mixed micelles was determined after destruction of the phospholipids with perchloric acid $\left(\mathrm{HCLO}_{4}\right)$ to yield inorganic phosphate. Standard solutions were prepared as follows: 20/40/60/80/ $100 / 120 / 160 \mu \mathrm{l}$ of $0.5 \mathrm{mM}$ phosphate solution $(1.95 \mathrm{~g}$ $\mathrm{NaH}_{2} \mathrm{PO}_{4} \cdot \mathrm{H}_{2} \mathrm{O}$ dissolved in $250 \mathrm{ml}$ of $\mathrm{RO}$-water and subsequently diluted 100 times with RO-water) was introduced in triplicate in test-tubes. Test samples were prepared by dilution of the micellar dispersions 2.5 times with RO-water and $1.8 \mathrm{ml}$ of the diluted dispersion was subsequently desalted using PD-10 column chromatography (Pharmacia). The collected volume was $2.0 \mathrm{ml}$. Phosphate buffer $(1.8 \mathrm{ml}, 0.067 \mathrm{M})$ was also desalted using PD-10 column chromatography as control. Then, samples of the micellar dispersions and the control sample were 10 times diluted with RO-water. Next, samples of $190 \mu \mathrm{l}$ of the diluted micellar dispersions and the control were pipetted in triplicate into the test tubes. The tubes were covered by porcelain marbles and subsequently heated using a block heater (Techne Dri-block heater, Model DB 3H, PJ Brennan, Dublin) for $30 \mathrm{~min}$ (temperature was set at $180^{\circ} \mathrm{C}$ ). Next, the test tubes were cooled down to room temperature and $0.3 \mathrm{ml}$ of $70 \%$ perchloric acid was introduced in the tubes. The tubes were again covered by porcelain marbles and heated by the block heater (temperature at $180^{\circ} \mathrm{C}$ ) for at least $45 \mathrm{~min}$ until the solutions were clear. Next, $1 \mathrm{ml}$ RO-water, $0.5 \mathrm{ml} 1.2 \%$ hexaammoniummolybdate solution (1.25 g hexaammoniummolybdate in $100 \mathrm{ml}$ of RO-water) and $0.5 \mathrm{ml}$ of $5 \%(w / v)$ ascorbic acid (1.00 $\mathrm{g}$ in $20 \mathrm{ml}$ of RO-water) were added to the test tubes. Subsequently, the tubes were covered by the porcelain marbles and placed in a water bath $\left(100^{\circ} \mathrm{C}\right)$ for $5 \mathrm{~min}$. After cooling down to room temperature, the absorbance of the solutions at $797 \mathrm{~nm}$ was determined using a UV-vis spectrophotometer (UV mini-1240, Shimadzu, Japan) and the amount of phosphate in the samples was determined using the calibration curve as described above.

\section{Cytocompatibility of Vitamin K Loaded Mixed Micelles}

The viability of Caco-2 cells incubated with vitamin $\mathrm{K}$ loaded mixed micelles was evaluated by the XTT assay (32). The cells were seeded in 96-well plates at a density of $1 \times 10^{4}$ cells per well and incubated at $37^{\circ} \mathrm{C}$ with $5 \% \mathrm{CO}_{2}$ for $24 \mathrm{~h}$ to permit 
cells attachment. Because glychocholic acid is the main component of the formulation which can cause cytotoxicity (33), the concentration of the mixed micelles is reported in terms of glycocholic acid content. Konakion ${ }^{\circledR} \mathrm{MM}$ and vitamin $\mathrm{K}$ loaded mixed micelles $(2.5 \mathrm{mg} / \mathrm{ml})$ composed of EPC only and DSPE-PEG/EPG (10/90, 30/70 and 50/50, mol/mol, respectively) were diluted with Dulbecco's Modified Eagle's medium (blank DMEM). The final concentrations of glycocholic acid of the mixed micelles were from 0.12 to $1.20 \mathrm{mM}$ after addition of $20 \mu \mathrm{l}$ samples to $100 \mu \mathrm{l}$ DMEM culture medium. The control was empty micelles composed of DSPE-PEG/EPG $(50 / 50, \mathrm{~mol} / \mathrm{mol}$ ) (final concentration of glycocholic acid was $1.2 \mathrm{mM}$ ). To investigate the viability of caco-2 cells at higher concentrations of mixed micelles, formulations composed of DSPE-PEG/EPC (50/50, mol/mol) and EPC only were used. They were diluted with Dulbecco's Modified Eagle's medium (blank DMEM) and their final concentrations of glycocholic acid were from 0.12 to $12 \mathrm{mM}$. $100 \mu \mathrm{l}$ of above mixed micelles was added to each well. After $24 \mathrm{~h}$ of culturing at $37^{\circ} \mathrm{C}$, the medium was removed and $50 \mu \mathrm{l}$ XTT solution $(1 \mathrm{mg} / \mathrm{ml}$ in plain RPMI 1640, containing $25 \mu \mathrm{M}$ PMS) was added per well and the plates were subsequently incubated for $1.5 \mathrm{~h}$ at $37^{\circ} \mathrm{C}$, after which the absorbance at $490 \mathrm{~nm}$ with a reference wavelength of $655 \mathrm{~nm}$ was measured by ELISA microplate reader (Biorad Novapath).

\section{RESULTS AND DISCUSSION}

\section{Preparation of Mixed Micelles with and Without Vitamin K Loading}

Vitamin K loaded mixed micelles composed of EPC, with and without DSPE-PEG, and a fixed molar ratio of 0.22 vitamin $\mathrm{K}$ versus total lipids, were prepared by hydration of a lipid film with a glycocholic acid solution, resulting in turbid dispersions probably consisting of large unilamellar liposomes coexisting with flat bilayers as has been reported earlier $(34,35)$. The turbid dispersions became gradually translucent upon magnetic stirring, and finally transparent micellar dispersions were obtained after stirring for $4 \mathrm{~h}$. The average size of the dispersed particles after stirring for $4 \mathrm{~h}$ and before filtration was between 85 and $215 \mathrm{~nm}$ (Fig. 1a) with high polydispersity (Fig. 1b). Such high polydispersity suggests the coexistence of micelles and larger vesicles.

There are at least two factors involved in the change from turbid to transparent dispersions. First, the molecular volume (V) of the phospholipid EPG is approximately equal to the polar surface cross-area $\left(\mathrm{A}_{\mathrm{o}}\right)$ and the length $(\mathrm{L})$ of the hydrophobic chain, meaning that the packing parameter $\mathrm{PP}=\mathrm{V} /$ $\left(\mathrm{A}_{\mathrm{o}} \times \mathrm{L}\right)(36)$, is close to 1 and as a consequence this phospholipid tends to form planar bilayers (37). The insertion of glycocholic acid in the phospholipid vesicles, due to its flat structure, can increase $A_{o}$ which results in a reduction of the PP. As a consequence, part of the vesicles is transformed into highly curved mixed micelles (38) as shown in Fig. 2a. This glycocholic acid induced vesicles-to-micelles transition process occurs in three steps (39). Glycocholic acid initially partitions between water and the outermost planar bilayer and subsequently penetrates and peels off the planar lipid bilayers one after the other yielding smaller bilayer flakes (stage 1). Subsequently, after being peeled off, phospholipid molecules and glycocholic acid molecules can self-assemble into micelles by hydrophobic interaction (stage 2). The other factor of importance is the presence of DSPE-PEG in planar bilayers. Even at low ratios of DSPE-PEG ( $5 \mathrm{~mol}^{\%} \%$ ) (40), its presence reduces the size of planar bilayers composed of EPC (40) and increases the curvature of the particles. With increasing DSPE-PEG in the bilayer, the PP of mixed micelles decreases and can reach a value of $<0.5$ (37). As a consequence, larger vesicles and planar bilayers are transformed into smaller and spherical micelles or cylindrical micelles (36) as shown in Fig. 2a $(39,40)$.

After filtration through a membrane with pores of $200 \mathrm{~nm}$, the average sizes of large particles composed of EPG and DSPE-PEG decreased from $213 \pm 2 \mathrm{~nm}, 112 \pm 15 \mathrm{~nm}, 100$ $\pm 21 \mathrm{~nm}$ and $132 \pm 69 \mathrm{~nm}$ to $7.1 \pm 0.2 \mathrm{~nm}, 8.9 \pm 0.4 \mathrm{~nm}, 9.7$ $\pm 0.8 \mathrm{~nm}$ and $11.0 \pm 1.4 \mathrm{~nm}(n=3)$, respectively, for formulations with DSPE-PEG/EPC molar ratios increasing from 0/ 100 to 50/50 (Fig. 1a). The PDI also reduced substantially from $0.60-0.87$ to $<0.26$ (Fig. 1b). Figure 3 shows the calculated intensity weighted diameter before and after filtration for formulations with different molar fractions of DSPEPEG. Before filtration, size distributions by intensity showed that larger particles with diameters above $100 \mathrm{~nm}$ were present. Importantly, the intensity of these larger particles $(>100 \mathrm{~nm})$ decreased significantly and the intensity of the smaller particles of $\sim 10 \mathrm{~nm}$ increased correspondingly after the first filtration. Finally, a fraction of large particles was not detected anymore after 3 filtration cycles and only smaller particles of $\sim 10 \mathrm{~nm}$ with a unimodal distribution were present in the dispersions (Fig. 3). Through filtration, larger particles like flat bilayers or vesicles are subjected to both mechanical shear forces when pressed through the pores of the membrane (41) and the high pressure differential (42) across the filter. Spherical mixed micelles are likely being squeezed off from the cylindrical micelles (43) during their passage through the pores (Fig. 2b).

\section{Lipids Recovery and Vitamin K Loading Capacity}

The lipid recovery was determined according to Rouser (31). For the mixed micelles with 0.22 molar ratio of vitamin $\mathrm{K}$ versus total lipids, 91-96\% of the lipids was recovered after 3 filtration cycles for the various mixed micelles (Fig. 4). 
Fig. I Z-average diameter (a) and polydispersity index (PDI) (b) of vitamin $\mathrm{K}$ loaded mixed micelles composed of different molar ratio of DSPE-PEG/EPC before and after filtrations. a

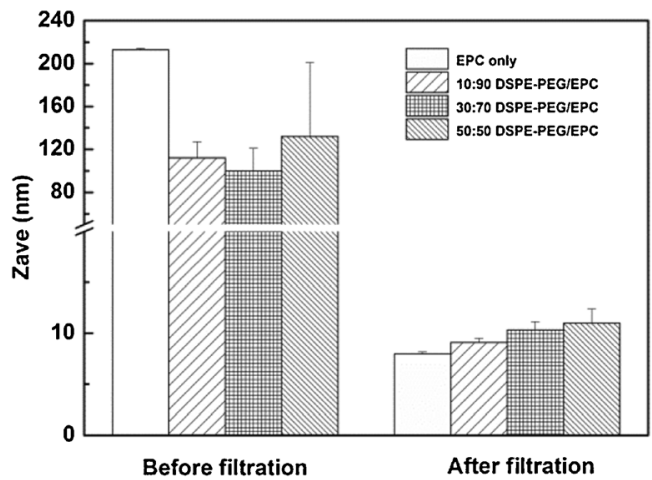

b

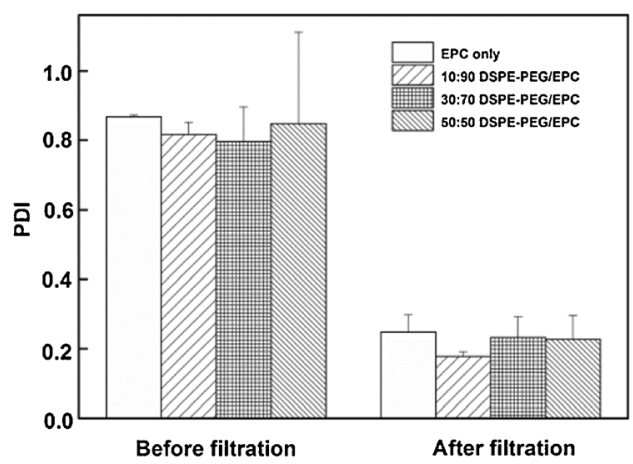

The vitamin K recovery, defined as the percentage of vitamin $\mathrm{K}$ solubilized in the mixed micelles divided by the added amount of vitamin $\mathrm{K}$ was $96-100 \%$ after three cycles of filtration (Fig. 4). The vitamin K loading capacity of the mixed micelles, defined as the percentage the mass of vitamin $\mathrm{K}$ divided by the total mass of the mixed micelles, decreased from $10.8 \pm 0.5 \%$ to $5.0 \pm 0.2 \%$ with increasing molar fraction of DSPE-PEG. The reason for this decrease in loading is that the total mass of lipids increased when EPC was replaced by higher-molecular-weight DSPE-PEG 2000.

To get insight into the maximum vitamin $\mathrm{K}$ loading capacity of the mixed micelles composed of 50/50 DSPE-PEG/ $\mathrm{EPC}$, an increasing amount of vitamin $\mathrm{K}$ was added to a fixed amount of total lipids (molar ratio of vitamin $\mathrm{K}$ and total lipids was increased from 0.22 to 0.44 and 0.88 , respectively). However, in that case, three more filtration cycles were needed to remove large particles with size above $200 \mathrm{~nm}$. Table II shows that both the vitamin $\mathrm{K}$ recovery $(91.3 \pm 2.0 \%)$, and the lipid recovery $(89.5 \pm 4.1 \%)$ was high after the 6 successive filtration cycles when the feed of vitamin K was 0.44 (mol/ mol lipids). However, vitamin $\mathrm{K}$ recovery decreased significantly to $42.6 \pm 1.5 \%$ and lipid recovery was $41.1 \pm 3.9 \%$ when the feed of vitamin $\mathrm{K}$ was further increased to 0.88 (mol/mol lipids).

The size of empty micelles after 3 filtration cycles ranged from $7.0 \pm 0.3$ to $9.2 \pm 0.1 \mathrm{~nm}$ with increasing DSPE-PEG content (Fig. 5a). The PDI was $<0.2$ for all empty micelles (Fig. 5b). The size of vitamin $\mathrm{K}$ loaded micelles (at a feed of 0.22 molar ratio of vitamin $\mathrm{K}$ versus total lipids) after filtration increased from $7.1 \pm 0.2$ to $11.0 \pm 1.4 \mathrm{~nm}$ with increasing DSPE-PEG content (Fig. 5a), which is in good agreement with the average thickness of around 1.5-3.5 nm for PEG corona of DSPE-PEG2000 (22,44). The PDI was $<0.2$ for all vitamin $\mathrm{K}$ loaded micelles (Fig. 5b), which points to a narrow particle size distribution. Figure $5 \mathrm{c}$ shows the zeta potentials of the different micelles. The low zeta potential of $-22.7 \pm 3.6 \mathrm{mV}$ for the mixed micelles composed of bile salt and EPC is caused by deprotonation of the $\mathrm{COOH}$ groups of glycocholic acid in

a

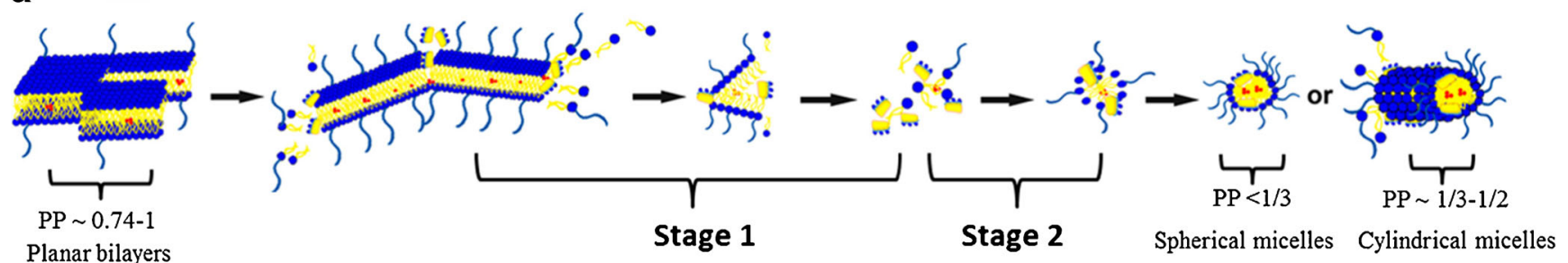

b

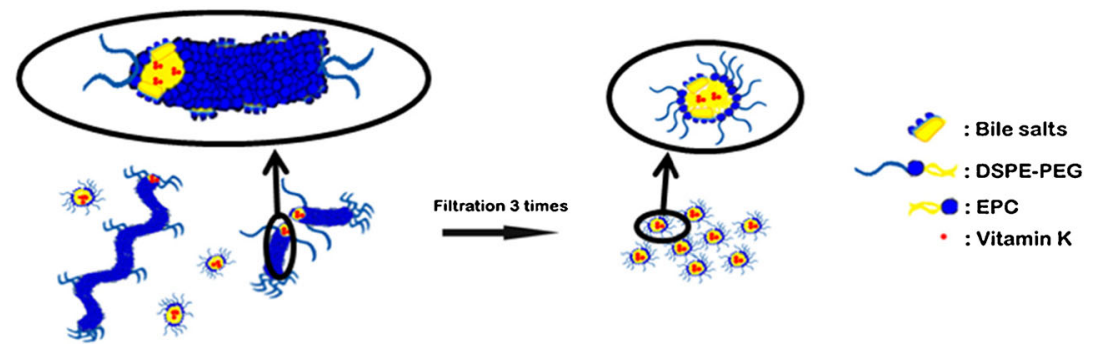

Fig. 2 A schematic mechanism of the formation of micelles from planar phospholipid bilayers during hydration of a film in a bile salt solution under stirring before filtration (a), and the size reduction after repeated filtrations through a $0.2 \mu \mathrm{m}$ filter (b). 
a
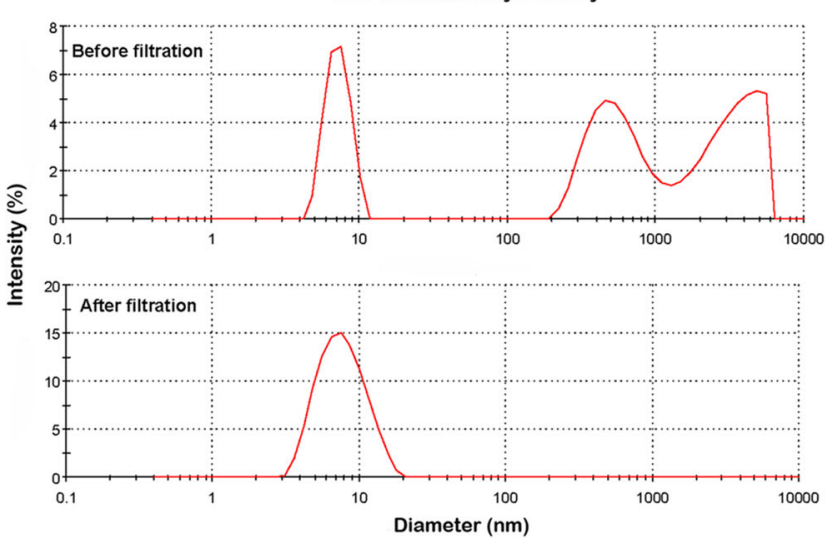

C

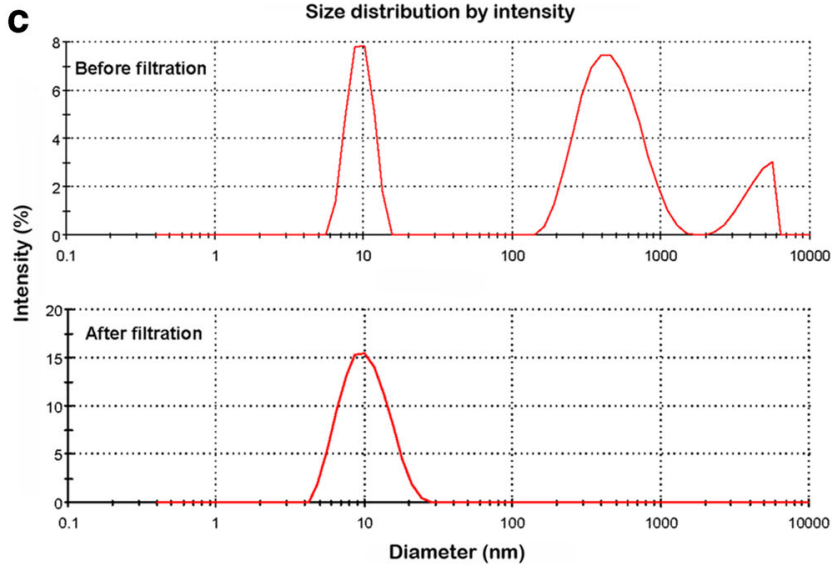

b
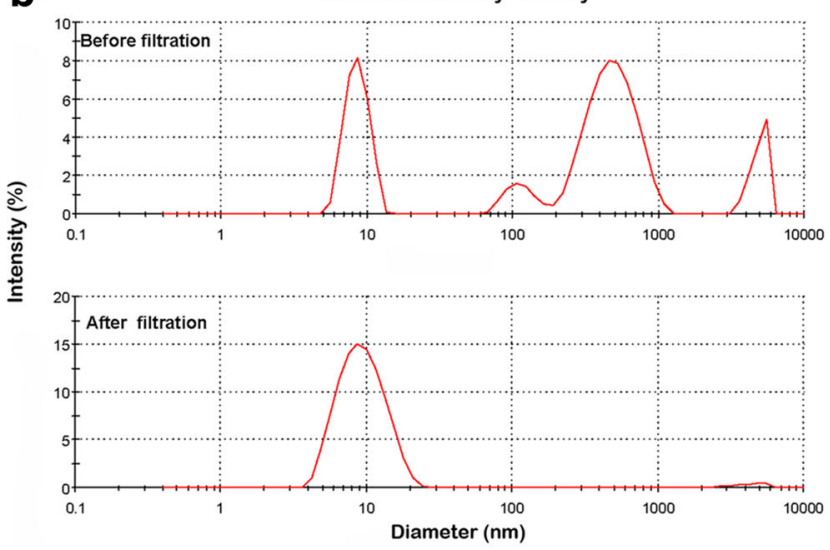

d
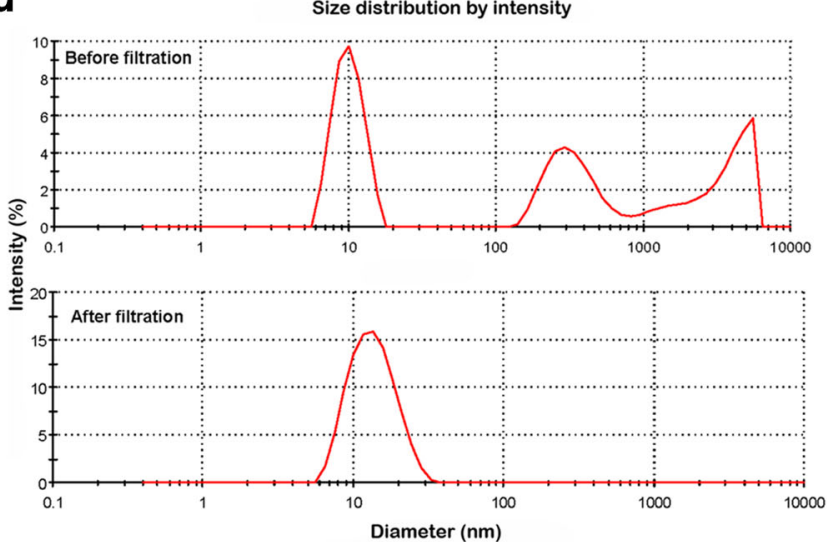

Fig. 3 Size intensity weighted diameter of different vitamin K loaded mixed micelles composed of EPC only (a), and DSPE-PEG/EPC with molar ratio's I0/90 (b), 30/70 (c) and 50/50 (d) before and after 3 cycles of filtration, respectively.

phosphate buffer. With an increase of the fraction of DSPEPEG from $0 / 100$ to $50 / 50(\mathrm{~mol} / \mathrm{mol})$ in the formulations, an increase of zeta potential from $-22.7 \pm 3.6$ to $-2.8 \pm 0.5 \mathrm{mV}$ was observed, demonstrating excellent shielding of the surface charge by PEG.

When the feed of vitamin $\mathrm{K}$ increased from 0.22 to 0.44 , the average size of the mixed micelles increased from 11.0 \pm 1.4 to $19 \pm 6 \mathrm{~nm}$ after 6 times filtration, because still a small fraction of bigger particles between 100 and $200 \mathrm{~nm}$ was present even after 6 filtration cycles. The majority of particles however had an average size of around $15 \mathrm{~nm}$ (Supplementary Fig. 1a). When the feed of vitamin K further increased from 0.44 to 0.88 ( $\mathrm{mol} / \mathrm{mol}$ lipids), the micellar dispersions needed to be diluted to avoid occlusion during the filtration. The average size of the mixed micelles ended up at $44 \pm 5 \mathrm{~nm}$ after the six filtration cycles. The average size of a minor fraction of micelles was around $18 \mathrm{~nm}$ but the majority had a size of between 100 and $200 \mathrm{~nm}$ (Supplementary Fig. 1b).

The morphology of the mixed micelles composed of DSPE-PEG/EPC 50/50 (mol/mol) with vitamin $\mathrm{K}$ feed molar ratio of 0.22 ( $\mathrm{mol} / \mathrm{mol}$ lipids) was investigated by TEM analysis (Fig. 6). Figure 6a (arrows) shows several large particles of approximately $150 \mathrm{~nm}$ before filtration which confirmed the size as determined by DLS (Fig. 3d). After the first filtration cycle, cylindrical structures of up to approximately $100 \mathrm{~nm}$ in length can be seen besides spherical micelles (Fig. 6b), which are common shapes of mixed micelles

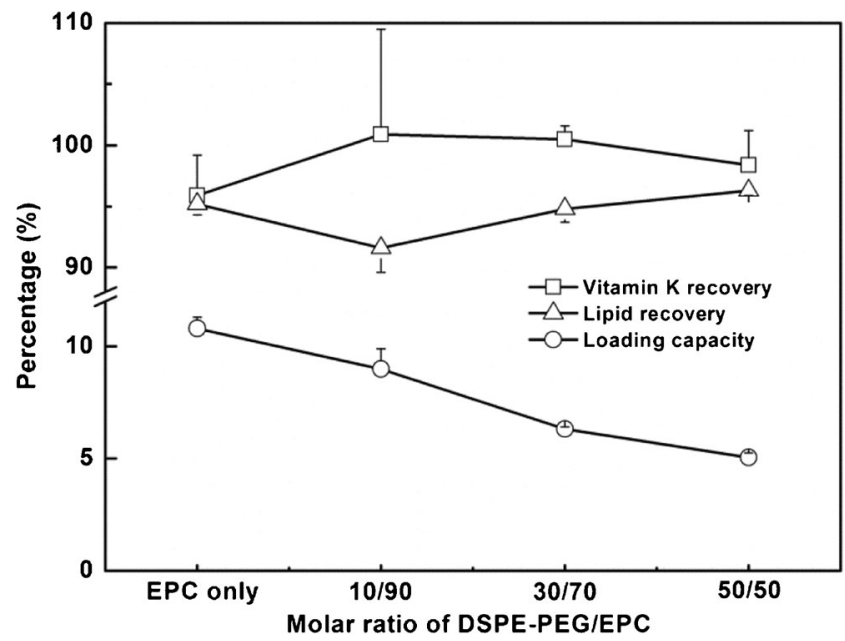

Fig. 4 Vitamin K recovery/loading and lipid recovery of mixed micelles composed of different molar ratio of DSPE-PEG/EPC ( $n=3$ independently prepared batches). 
Table II Influence of Vitamin K Feed (Molar Ratio of Vitamin K Versus Total Lipids) on the Loading Capacity of Mixed Micelles Composed of DSPE-PEG/ EPC 50/50 ( $\mathrm{mol} / \mathrm{mol})$ ( $n=3$ Independently Prepared Batches)

\begin{tabular}{lllll}
\hline Molar ratio & $\begin{array}{l}\text { Vitamin K } \\
\text { recovery (\%) }\end{array}$ & $\begin{array}{l}\text { Lipid } \\
\text { recovery }(\%)\end{array}$ & $\begin{array}{l}\text { Loading capacity } \\
(\mathrm{w} \%)\end{array}$ & $\begin{array}{l}\text { Size } \\
(\mathrm{nm})\end{array}$ \\
\hline 0.22 & $98.4 \pm 2.8$ & $96.3 \pm 0.4$ & $5.0 \pm 0.2$ & $11.0 \pm 1.4$ \\
0.44 & $91.3 \pm 2.0$ & $89.5 \pm 4.1$ & $9.9 \pm 0.2$ & $19 \pm 6$ \\
0.88 & $42.6 \pm 1.5$ & $41.1 \pm 3.9$ & $18.4 \pm 0.5$ & $44 \pm 5$ \\
\hline
\end{tabular}

composed of phospholipids and bile salts (40). One explanation for the formation of cylindrical structures is that TEM images show the shape of mixed micelles in their dry state. Thus, during the evaporation of water for the preparation of the specimen, increasingly higher concentrations of electrolytes such as phosphate buffer screen the electrostatic repulsion and promote particle aggregation (45). Also, PEG can induce lipid fusion in the dry state $(46,47)$, finally resulting in cylindrical structures as shown in Fig. 6b. Importantly, after 3 filtration cycles, although the effect of drying on the shape of micelles can also be observed in Fig. 6c, in which several small mixed micelles fused into pearl-necklace-like structures are seen (48), mostly spherically shaped mixed micelles with diameter around $10 \mathrm{~nm}$ were present in the sample of Fig. 6c.

Like for conventional surfactants, the formation of mixed micelles can be demonstrated using the fluorescent probe pyrene. The pyrene fluorescence intensity ratio of $\mathrm{I}_{338} / \mathrm{I}_{333}$ is plotted as a function of concentration of glycocholic acid in Supplementary Fig. 2. The CMC of mixed micelles composed of EPC only was $4.6 \mu \mathrm{M}$ glycocholic acid. For mixed micelles composed of DSPE-PEG/EPG (50/50), their CMC was $3.9 \mu \mathrm{M}$ glycocholic acid. Within the experimental error, the CMCs of both mixed micelles are equal.

\section{Stability and Vitamin K Retention at Acid pH}

To study the stability of various mixed micelles, size changes were measured when the $\mathrm{pH}$ was stepwise decreased from 7.3 to 1.6 and subsequently reversed to 7.3. The size of micelles composed of EPG only was $80 \mathrm{~nm}$ after the $\mathrm{pH}$ was lowered to

\section{a}

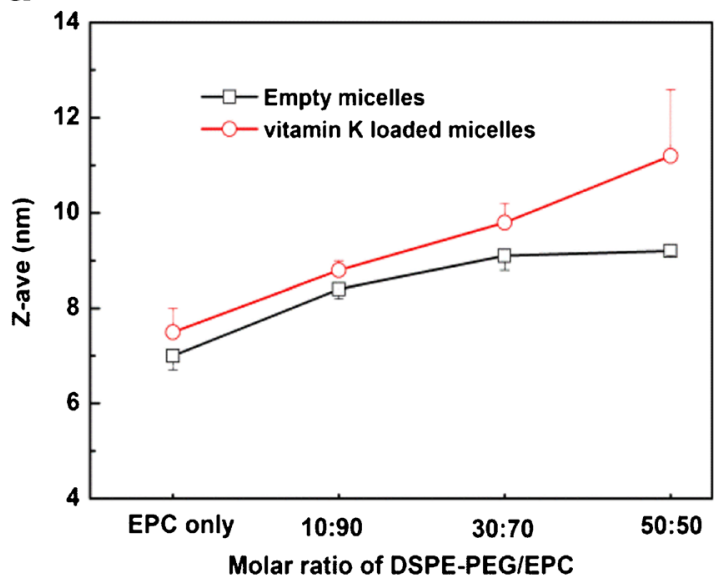

b

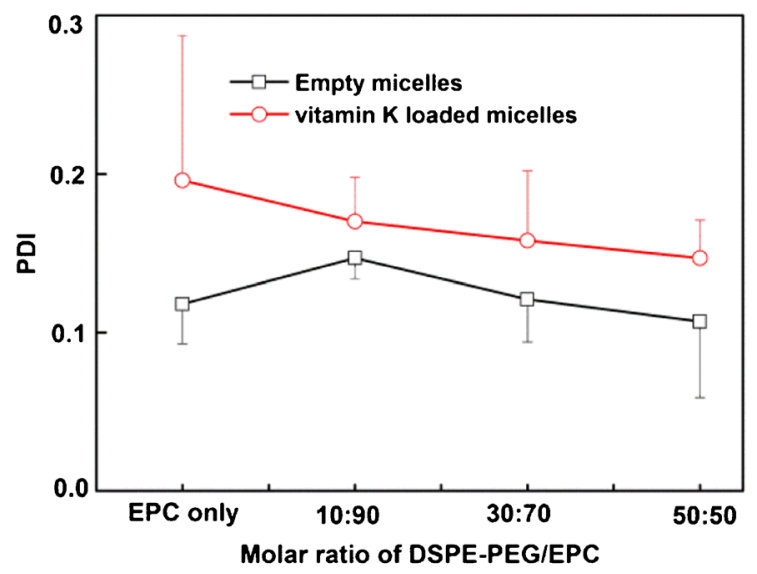

C

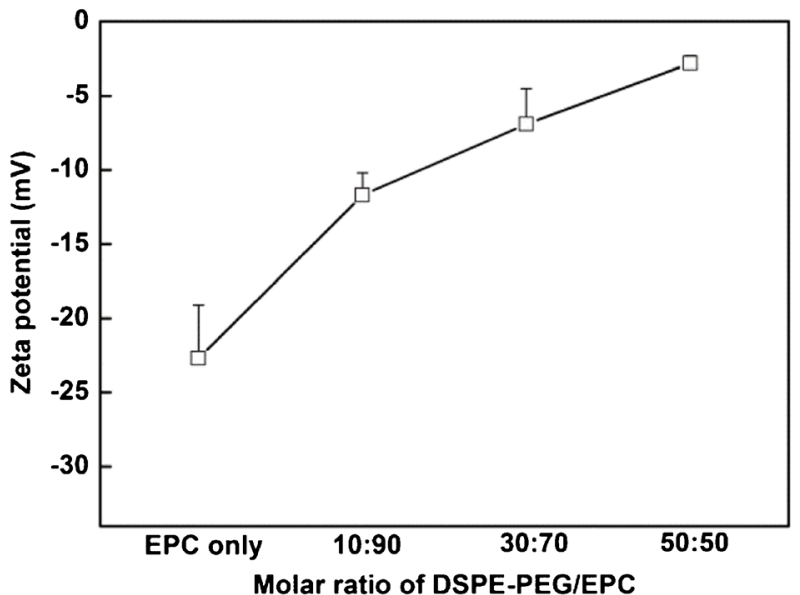

Fig. 5 Z-average hydrodynamic diameter (a), polydispersity index (PDI) (b) and zeta potential (c) of mixed micelles with or without vitamin $\mathrm{K}$ as a function of molar ratio of DSPE-PEG/EPC ( $n=3$ independently prepared batches). 
Fig. 6 TEM images of vitamin $\mathrm{K}$ loaded mixed micelles composed of DSPE-PEG/EPC 50/50 and a vitamin $\mathrm{K}$ feed molar ratio of 0.22 (mol/mol lipids): before filtration (a), after the first filtration cycle (b) and after 3 filtration cycles (c).
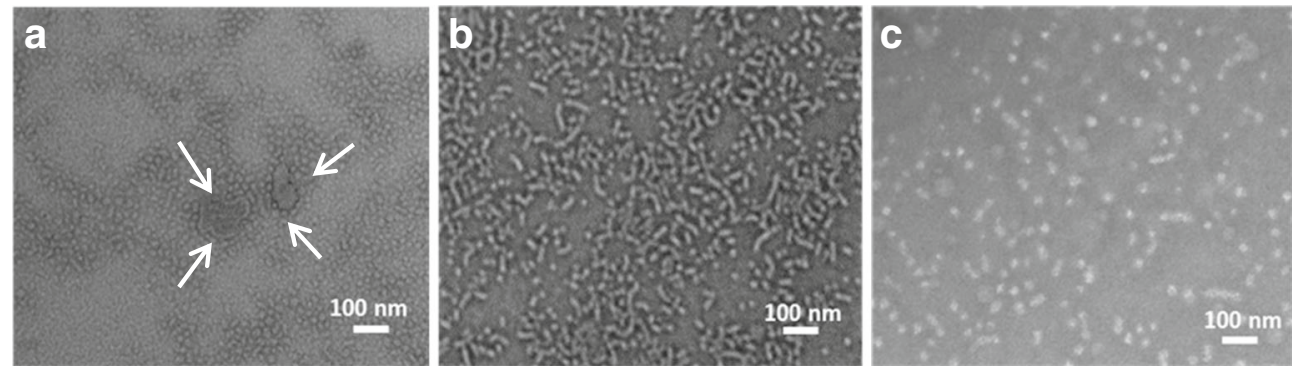

4.2 (Supplementary Fig. 3a), while turbidity appeared after the $\mathrm{pH}$ was further lowered to 3.5 (Supplementary Fig. 4a). Apparently, the micelles became unstable and aggregated or coalesced, resulting in precipitation of vitamin $\mathrm{K}$ (Supplementary Fig. 4b). The $\mathrm{pH}$ of the dispersions was then stepwise lowered to 1.6 and they were subsequently incubated for $1 \mathrm{~h}$ at $37^{\circ} \mathrm{C}$. After centrifugation, the amount of vitamin $\mathrm{K}$ in the supernatants as measured by HPLC was found to be only $1.5 \pm 0.1$ and $6.3 \pm 0.3 \%$ of the initial vitamin $\mathrm{K}$ loading for the commercial formulation and mixed micelles composed of EPC only, respectively (Supplementary Fig. 5).

For mixed micelles composed of DSPE-PEG/EPC 10/90 $(\mathrm{mol} / \mathrm{mol})$, their size increased from 9 to $100 \mathrm{~nm}$ and dispersions became translucent, when the $\mathrm{pH}$ was lowered stepwise to 1.6 (Supplementary Fig. 3b). It was further measured that $58.2 \pm 0.9 \%$ of vitamin $\mathrm{K}$ remained solubilized in the mixed micelles (Supplementary Fig. 5). Mixed micelles composed of DSPE-PEG/EPG 30/70 ( $\mathrm{mol} / \mathrm{mol})$ remained transparent and the size increased only slightly from 10 to $20 \mathrm{~nm}$ when the $\mathrm{pH}$ was lowered from 7.3 to 1.6 (Supplementary Fig. 3c). The size remained around $20 \mathrm{~nm}$ (with PDI at around 0.2) when the dispersions were kept at $\mathrm{pH} 1.6$ at $37^{\circ} \mathrm{C}$ for $80 \mathrm{mins}$ (Supplementary Fig. 3e), and around 90\% of vitamin K remained solubilized at pH 1.6 (Supplementary Fig. 5). Interestingly, the size of the mixed micelles composed of DSPE-PEG/EPC 50/50 ( $\mathrm{mol} / \mathrm{mol}$ ) did not show any change when the $\mathrm{pH}$ was lowered from 7.3 to 1.6 and vice versa (Supplementary Fig. 3d) and remained around $12 \mathrm{~nm}$ with PDI of $\sim 0.2$ at pH 1.6 and $37^{\circ} \mathrm{C}$ for 80 min (Supplementary Fig. 3f), while more than $90 \%$ of vitamin $\mathrm{K}$ remained solubilized at pH 1.6 (Supplementary Fig. 5). The stability of mixed micelles was further investigated in FaSSGF (pH 1.5). Konakion ${ }^{\circledR}$ MM was not stable and coalescence of vitamin $\mathrm{K}$ was observed within $1 \mathrm{~h}$ at $37^{\circ} \mathrm{C}$ (Fig. 7). However, mixed micelles composed of 50/50 DSPE-PEG/EPC ( $\mathrm{mol} / \mathrm{mol})$ remained stable and kept transparent in FaSSGF for at least
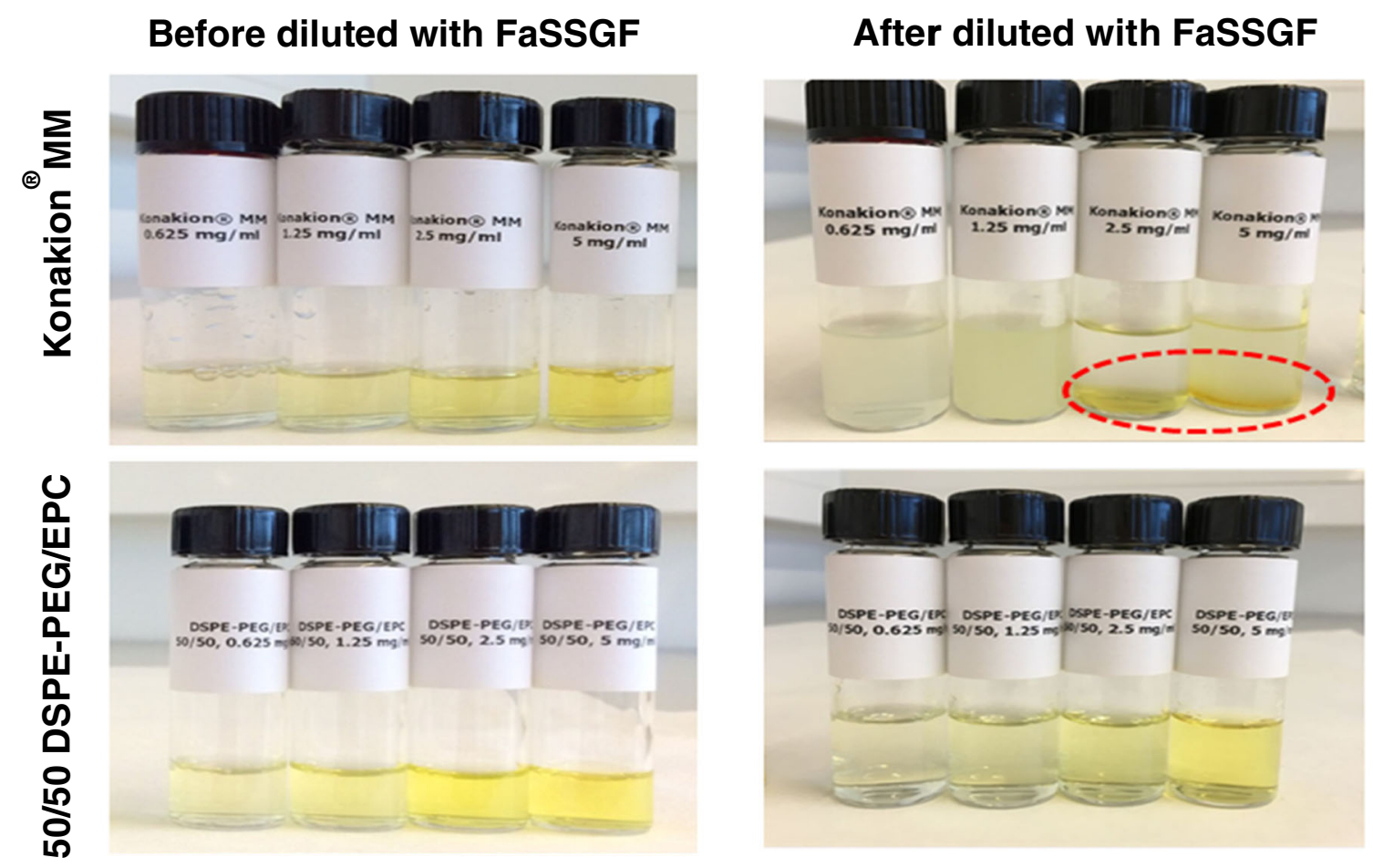

Fig. 7 Photographs of mixed micelles composed of EPC only (Konakion ${ }^{\circledR}$ MM) and 50/50 DSPE-PEG/EPC (mol/mol) with different vitamin K concentrations (from 0.625 to $5 \mathrm{mg} / \mathrm{ml}$ ), incubated for $\mathrm{l} h$ at $37^{\circ} \mathrm{C}$ with and without FaSSGF. 
a

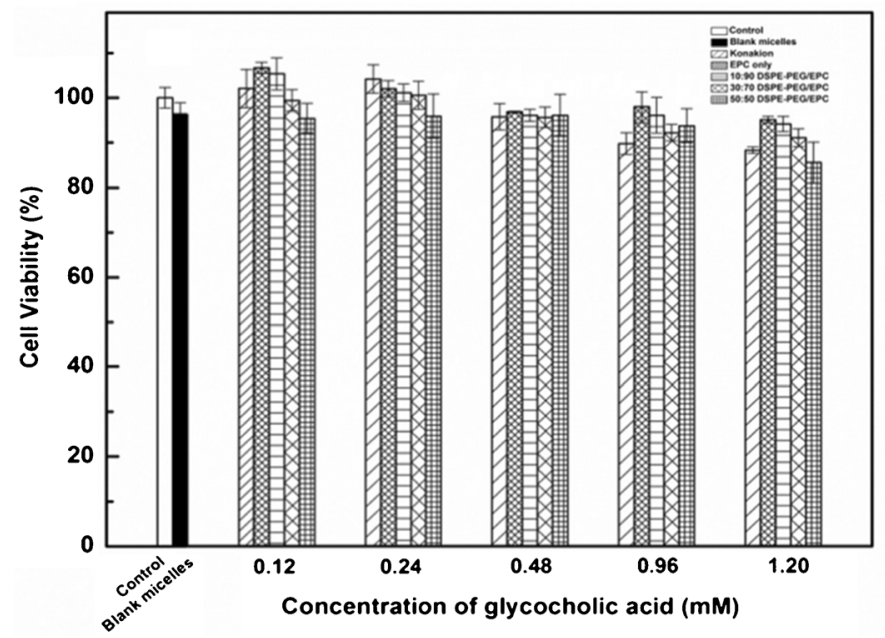

b

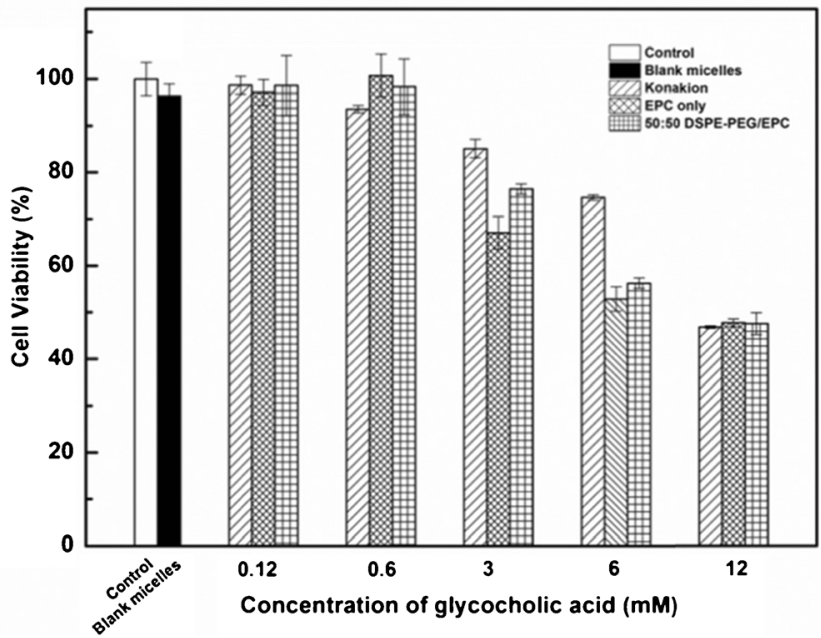

Fig. 8 In vitro cell viability of Caco-2 cells incubated for $24 \mathrm{~h}$ with mixed micelles composed of EPC only and different molar ratio of DSPE-PEG/EPC (from I 0/90 to $50 / 50, \mathrm{~mol} / \mathrm{mol}$ ) and Konakion ${ }^{\circledR} \mathrm{MM}$.

$1 \mathrm{~h}$ at $37^{\circ} \mathrm{C}$. To conclude, due to the steric stabilization of mixed micelles by PEG, the formation of aggregated particles can thus be avoided by introducing PEG in the formulation.

\section{Cell Viability Study}

The effect of vitamin $\mathrm{K}$ loaded mixed micelles of different compositions as well as the commercial formulation Konakion ${ }^{\circledR} \mathrm{MM}$ on the viability of $\mathrm{Caco}-2$ cells was studied using the XTT assay. Caco-2 cells were selected as a model for small intestinal epithelial cells $(49,50)$. As shown in Fig. 8a, the cell viability after $24 \mathrm{~h}$ of incubation with different formulations with concentration of glycocholic acid ranging from 0.12 to $1.20 \mathrm{mM}$ was $>90 \%$. Figure $8 \mathrm{~b}$ also shows the in vitro cell viability of Caco-2 cells incubated with commercial formulation Konakion ${ }^{\circledR} \mathrm{MM}$ and mixed micelles composed of EPC only or DSPE-PEG/EPC (50/50 mol/mol) at higher concentrations of glycocholic acid (from 0.12 to $12 \mathrm{mM}$ ) for $24 \mathrm{~h}$. Cell viability decreased from 95 to $50 \%$ when the concentration of glycocholic acid increased from 0.12 to $12 \mathrm{mM}$, respectively. The reduced cell viability is due to high concentration of glycocholic acid $(33,51)$. Therefore, mixed micelles composed of DSPE-PEG/EPG showed good cytocompatibility which is comparable with that of the commercial formulation Konakion ${ }^{\circledR}$ MM.

\section{CONCLUSIONS}

In this study, vitamin $\mathrm{K}$ loaded mixed micelles composed of DSPE-PEG, EPC and glycocholic acid were successfully prepared by a film hydration method. Extrusion through a membrane filter plays a crucial role in preparation of mixed micelles with final sizes at around $10 \mathrm{~nm}$. Vitamin $\mathrm{K}$ loaded mixed micelles composed of EPC, DSPE-PEG 2000 and glycocholic acid showed high loading capacity and good cytocompatibility for Caco-2 cells, which was comparable to mixed micelles without DSPE-PEG (i.e. Konakion $®$ MM). Additionally, mixed micelles of EPC, DSPE-PEG 2000 and glycocholic acid can prevent both the formation of larger aggregates and coalescence of vitamin $\mathrm{K}$ in the micellar dispersions at low $\mathrm{pH}$ thus is superior to Konakion ${ }^{\circledR} \mathrm{MM}$ with regard to their gastric stability. Therefore, mixed micelles of EPC, DSPE-PEG 2000 and glycocholic acid are a promising oral formulation of vitamin $\mathrm{K}$ for the prophylaxis and treatment of VKDB in neonates and infants suffering from cholestasis. More work about the intestinal transport of vitamin $\mathrm{K}$ loaded mixed micelles composed of EPC, DSPE-PEG 2000 and glycocholic acid will be conducted in the near future.

\section{ACKNOWLEDGMENTS AND DISCLOSURES}

The research was partially supported by China Scholarship Council.

Open Access This article is distributed under the terms of the Creative Commons Attribution 4.0 International License (http://creativecommons.org/licenses/by/4.0/), which permits unrestricted use, distribution, and reproduction in any medium, provided you give appropriate credit to the original author(s) and the source, provide a link to the Creative Commons license, and indicate if changes were made.

\section{REFERENCES}

1. Vermeer C. Gamma-carboxyglutamate-containing proteins and the vitamin K-dependent carboxylase. Biochem J. 1990;266:625. 
2. Siperstein M, Chaikoff I, Reinhardt W. $\mathrm{C}^{14}$-Cholesterol. 5. Obligatory function of bile in intestinal absorption of cholesterol. J Biol Chem. 1952;198:111-4.

3. Shearer MJ. Vitamin K, in Parenteral Nutrition. Gastroenterology. 2009;137:105-18.

4. Lippi G, Franchini M. Vitamin K in neonates: facts and myths. Blood Transfus. 2011;9:4.

5. Chalmers E. Neonatal coagulation problems. Arch Dis Child-Fetal. 2004;89:475-8.

6. Available from: https://www.medicines.org.uk/emc/printdocument?documentId=1699

7. Von Kries R, Hachmeister A, Göbel U. Oral mixed micellar vitamin $\mathrm{K}$ for prevention of late vitamin $\mathrm{K}$ deficiency bleeding. Arch Dis Child-Fetal. 2003;88:109-12.

8. Eckhardt U, HorzJA, Petzinger E, et al. The peptide based thrombin inhibitor CRC 220 is a new substrate of the basolateral rat liver organic anio-transporting polypeptide. Hepatology. 1996;24:380-4.

9. Van Hasselt PM. Vitamin K prophylaxis revisited: focus on risk factors. 2009

10. Gothwal A, Khan I, Gupta U. Polymeric micelles: recent advancements in the delivery of anticancer drugs. Pharm Res. 2016;33:18-39.

11. Fagerberg JH, Karlsson E, Ulander J, Hanisch G, Bergström CA. Computational prediction of drug solubility in fasted simulated and aspirated human intestinal fluid. Pharm Res. 2015;32:578-89.

12. Iqbal J, Hussain MM. Intestinal lipid absorption. Am J Physiol Endocrinol Metab. 2009;296:1 183-94.

13. Werner A, Kuipers F, Verkade HJ. Fat absorption and lipid metabolism in cholestasis. In: Trauner M, Jansen PLM, editors. Molecular pathogenesis of cholestasis. New York: Landes Bioscience; 2004. p. 314-28.

14. Hernell O, Staggers JE, Carey MC. Physical-chemical behavior of dietary and biliary lipids during intestinal digestion and absorption. 2. Phase analysis and aggregation states of luminal lipids during duodenal fat digestion in healthy adult human beings. Biochemistry. 1990;29:2041-56.

15. Hofmann AF, Borgström B. The intraluminal phase of fat digestion in man: the lipid content of the micellar and oil phases of intestinal content obtained during fat digestion and absorption. J Clin Invest. 1964;43:247.

16. Madenci D, Salonen A, Schurtenberger P, Pedersen JS, Egelhaaf SU. Simple model for the growth behaviour of mixed lecithin-bile salt micelles. Phys Chem Chem Phys. 2011;13:3171-8.

17. Khan J, Rades T and Boyd B. The precipitation behavior of poorly water-soluble drugs with an emphasis on the digestion of lipid based formulations. Pharm Res. 2015: 1-15.

18. Rupp C, Steckel H, Müller BW. Solubilization of poorly watersoluble drugs by mixed micelles based on hydrogenated phosphatidylcholine. Int J Pharm. 2010;395:272-80.

19. Hauss DJ. Oral lipid-based formulations: enhancing the bioavailability of poorly water-soluble drugs. Boca Raton: CRC Press; 2007.

20. Immordino ML, Dosio F, Cattel L. Stealth liposomes: review of the basic science, rationale, and clinical applications, existing and potential. Int J Nanomed. 2006;1:297.

21. Lindqvist A, Rip J, van Kregten J, Gaillard PJ, HammarlundUdenaes M. In vivo functional evaluation of increased brain delivery of the opioid peptide DAMGO by Glutathione-PEGylated liposomes. Pharm Res. 2016;33:177-85.

22. Vukovic L, Khatib FA, Drake SP, et al. Structure and dynamics of highly PEG-ylated sterically stabilized micelles in aqueous media. J Am Chem Soc. 201 1;133:13481-8.

23. Carmona-Ribeiro AM. Lipid bilayer fragments and disks in drug delivery. Curr Med Chem. 2006;13:1359-70.

24. Pourjavadi A, Tehrani ZM, Moghanaki AA. Folate-conjugated pHResponsive nanocarrier designed for active tumor targeting and controlled release of gemcitabine. Pharm Res. 2016;33:417-32.
25. Dabholkar RD, Sawant RM, Mongayt DA, et al. Polyethylene glycol phosphatidyl-ethanolamine conjugate (PEG-PE)-based mixed micelles: some properties, loading with paclitaxel, and modulation of P-glycoprotein-mediated efflux. Int J Pharm. 2006;315:148-57.

26. Dangi J, Vyas S, Dixit V. Effect of various lipid-bile salt mixed micelles on the intestinal absorption of amphotericin-B in rat. Drug Dev Ind Pharm. 1998;24:631-5.

27. Brodie AF, Ballantine J. Oxidative phosphorylation in fractionated bacterial systems II. The role of vitamin K. J Biol Chem. 1960;235: 226-31.

28. Kalyanasundaram K, Thomas J. Environmental effects on vibronic band intensities in pyrene monomer fluorescence and their application in studies of micellar systems. J Am Chem Soc. 1977;99: 2039-44.

29. Soga O, van Nostrum CF, Ramzi A, et al. Physicochemical characterization of degradable thermosensitive polymeric micelles. Langmuir. 2004;20:9388-95.

30. Vertzoni M, Dressman J, Butler J, et al. Simulation of fasting gastric conditions and its importance for the in vivo dissolution of lipophilic compounds. Eur J Pharm Biopharm. 2005;60:413-7.

31. Rouser G, Fleischer S, Yamamoto A. Two dimensional thin layer chromatographic separation of polar lipids and determination of phospholipids by phosphorus analysis of spots. Lipids. 1970;5: 494-6.

32. Scudiero DA, Shoemaker RH, Paull KD, et al. Evaluation of a soluble tetrazolium/formazan assay for cell growth and drug sensitivity in culture using human and other tumor cell lines. Cancer Res. 1988;48:4827-33.

33. Tan Y, QiJ, Lu Y, Hu F, Yin Z, Wu W. Lecithin in mixed micelles attenuates the cytotoxicity of bile salts in Caco-2 cells. Toxicol In Vitro. 2013;27:714-20.

34. Lichtenberg D, Ahyayauch H, Alonso A, Goñi FM. Detergent solubilization of lipid bilayers: a balance of driving forces. Trends Biochem Sci. 2013;38:85-93.

35. Kozlov MM, Andelman D. Theory and phenomenology of mixed amphiphilic aggregates. Curr Opin Colloid Interface Sci. 1996;1: 362-6.

36. Israelachvili JN. Intermolecular and surface forces: with applications to colloidal and biological systems (Colloid Science). London: Academic; 1992.

37. Garbuzenko O, Barenholz Y, Priev A. Effect of grafted PEG on liposome size and on compressibility and packing of lipid bilayer. Chem Phys Lipids. 2005;135:117-29.

38. Jiang L, Wang K, Deng M, Wang Y, Huang J. Bile salt-induced vesicle-to-micelle transition in catanionic surfactant systems: steric and electrostatic interactions. Langmuir. 2008;24:4600-6.

39. Helenius A, Simons K. Solubilization of membranes by detergents. BBA-Biomembr. 1975;415:29-79.

40. Johnsson M, Edwards K. Liposomes, disks, and spherical micelles: aggregate structure in mixtures of gel phase phosphatidylcholines and poly (ethylene glycol)-phospholipids. Biochem J. 2003;85: 3839-47.

41. Clerc SG, Thompson TE. A possible mechanism for vesicle formation by extrusion. Biochem J. 1994;67:475.

42. Patty PJ, Frisken BJ. The pressure-dependence of the size of extruded vesicles. Biochem J. 2003;85:996-1004.

43. Wickner W, Schekman R. Membrane fusion. Nat Struct Mol Biol. 2008;15:658-64.

44. Johnsson M, Hansson P, Edwards K. Spherical micelles and other self-assembled structures in dilute aqueous mixtures of poly (ethylene glycol) lipids. J Phys Chem B. 2001;105:8420-30.

45. Cheng CY, Oh H, Wang TY, Raghavan SR, Tung SH. Mixtures of lecithin and bile salt can form highly viscous wormlike micellar solutions in water. Langmuir. 2014;30:10221-30. 
46. Malinin VS, Frederik P, Lentz BR. Osmotic and curvature stress affect PEG-induced fusion of lipid vesicles but not mixing of their lipids. Biochem J. 2002;82:2090-100.

47. Burgess SW, McIntosh TJ, Lentz BR. Modulation of poly (ethylene glycol)-induced fusion by membrane hydration: importance of interbilayer separation. Biochemistry. 1992;31: 2653-61.

48. Chen Q, Zhao H, Ming T, Wang J, Wu C. Nanopore extrusioninduced transition from spherical to cylindrical block copolymer micelles. J Am Chem Soc. 2009;131:16650-1.
49. Artursson P. Epithelial transport of drugs in cell culture. I: a model for studying the passive diffusion of drugs over intestinal absorbtive (Caco-2) cells. J Pharm Sci. 1990;79:476-82.

50. Parr A, Hidalgo IJ, Bode C, et al. The effect of excipients on the permeability of BCS Class III compounds and implications for biowaivers. Pharm Res. 2016;33:167-76.

51. Jørgensen L, Artursson P, Bechgaard E. Toxicological and absorption enhancing effects of glycofurol 75 and sodium glycocholate in monolayers of human intestinal epithelial (Caco-2) cells. Int J Pharm. 1993;95:209-17. 